\title{
Breakthrough and Disruptive Innovation: A Theoretical Reflection
}

\author{
Kristina Rakic ${ }^{1 *}$
}

\begin{abstract}
The aim of this paper is a theoretical reflection which attempt is to define the breakthrough and disruptive innovation phenomena. For many years, scholars have studied the different forms of innovation and have provided new definitions and proposed different approaches to this topic. An issue discussed in this work is the differences between disruptive and breakthrough innovations, which can be perceived as similar but are producing different effects in the industry and market structure, and as well in the product structure and the technological approach to develop an innovation. This paper aims to develop a univocal meaning in the literature, differentiating the two phenomena, and provides a framework for the analysis of the different forms of technological change, studying its pervasive influence on our economy.
\end{abstract}

Keywords: Disruptive innovation; breakthrough innovation; radical innovation; theoretical approach.

Submitted: May 22 2 nd $2020 /$ Approved: October $22^{\text {nd }}, 2020$

\section{Introduction}

Innovation is a wide field of research, one which many scholars have attempted to study from different points of view (economic, managerial, engineering and sociological). An innovation is something new, and in the literature 'newness' is considered under different perspectives as something new to the world (Kleinschmidt and Cooper, 1991; Lee and $\mathrm{Na}, 1994$; Olson et al., 1995), new to the market (Lee and Na, 1994; Ali et al., 1995; Atuahene-Gima, 1995; Olson et al., 1995), new to the customer (Ali et al., 1995; Atuahene-Gima, 1995; Olson et al., 1995) and, finally, new to the firm and the industry (Kleinschmidt and Cooper, 1991; Green et al., 1995; Olson et al., 1995; O’Connor, 1998).

In management and engineering, the different typologies of innovation are well analysed and scholars generated multiple approaches to innovation field. Several typologies of innovation occur in the literature: architectural innovation, component innovation, discontinuous innovation, business model innovation, competence enhancing or destroying innovations. Among all those categorization, one particular aspect is relevant: the difference between radical and incremental innovation. These concepts seem clearly explained and well defined in the literature (e.g., Kline and Rosenberg, 1986; Pavitt, 2005). Moreover, the ability to define the deepness of radical innovation is linked to the concepts of breakthrough and disruptive innovation. Other scholars, such as Levinthal, Tripsas, O'Connor and Markides (among many others), continued to contribute to the innovation literature considering these pillars. However, they did not always share a common terminology, hence they explain different phenomena. Also Garcia and Calantone (2002) in their literature review maintained that scholars have created confusion among the different definitions of innovation typologies, and Markides $(2006,2010)$ called for an improvement of the theory related to disruptive innovation.

In this work, the issue of radical, breakthrough and disruptive innovation is particularly discussed. Those two phenomena appear very similar, but the use in different context and the way in which scholars adopt those definitions, reflect the assumption that breakthrough innovation is something that enhance the competences of the firms, refers to the technological dimension of a product, and it is more planned than a serendipitous event. Instead, the disruptive innovation, such as proposed by Christensen in 1997, refers more to a change in the market, a change in the competitors' structure causing the failure of the incumbents, and a change in the business model adopted by firms. Here it is proposed a theoretical reflection on the two different phenomena, which are interpreted elsewhere as very similar. Actually, this comparison calls for a deeper understanding of the theory, inexorably leading to different understandings of the competitive position of the firms within they environments.

Moreover, it is argued that disruptive innovations, as defined by Christensen $(1997,2003)$, are a very rare phenomenon, mainly analysed in the context of semi-finished products.

On one hand, there is a reflexion on the theory generated starting from 1997 since now about the role of disruptive innovation; on the other hand, we propose a different conceptualization of the disruption process created by technology push. Despite scholars always referred to those topics in an interchangeable way, we argue that there exists a significant difference. While the disruptive innovation process refers to a change in the market structure, the breakthrough innovation, in contrast, reflects a radical change in the technology or in the product range. So, even if we can assume that both processes are relatively radical in their core, they lead to two separated phenomena. Even if those two phenomena can intersect each other, the outcome and the result leads to a different outcome.

According to Wohlin (2014), to define the relevant literature, we follow a theoretical approach based on a snowball methodology. After searching the keyword "disruptive innovation" and "breakthrough innovation", in Google Scholar, the reading of several papers led the author to develop the present theoretical framework. To check the snowball effect, a co-citation analysis has been done.

1) Department of Economics and Management "M. Fanno", Univeristy of Padova, Italy

* Corresponding author: kristina.rakic@unipd.it

ISSN: 0718-2724. (http://jotmi.org)

Journal of Technology Management \& Innovation @ Universidad Alberto Hurtado, Facultad de Economía y Negocios. 
This paper is structured as follows. Section 2 summarises the typologies of innovation. Sections 3 analysis the difference existing among incremental and radical innovation. In section 4 an overview of the breakthrough innovation is provided, while in Section 5 the definition of disruptive innovation is articulated. In Section 6, a discussion of the different meanings and effects of disruptive and breakthrough innovation is provided. Finally, Section 7 contains the main conclusions and limitations of this work, along with some future research proposals.

\section{Typologies of innovation}

In the literature there are different conceptualizations of innovation. Innovation can be architectural (Henderson and Clark, 1990; Magnusson at al., 2003). The architectural innovation is considered the reconfiguration of existing modular resources, also at the firm level (Galunic and Eisenhardt, 2001), to obtain a new process, product, or business model (Sanchez and Mahoney, 1996; Galunic and Rodan, 1998). In this case the, according to Henderson and Clark (1990), the architectural innovation is "is the reconfiguration of an established system to link together existing components in a new way" (p. 5). It means that, also according to Sood and Tellis (2005), the core technology of the architectural innovation relies on the existing one. It is something about the changes needed to differently link the existing modules in order to obtain something slightly new.

In a complementary way, we refer to the innovation of components when only a part changes within the same architecture (Sood and Tellis, 2005). In the case of component innovation, the change occurs in the materials, parts, or in the new modules used to provide a new product.

Innovation can be discontinuous. In fact, according to Robertson (1967) "A discontinuous innovation involves the establishment of a new product and the establishment of new behavior patterns" (p. 16). According to Christensen (1997), sustaining technologies could be both discontinuous and radical, but they nonetheless ameliorate the performance of the already-existing products, without threatening incumbent firms. In this context, customers can value the realised improvements. Also Veryzer (1998) considers the discontinuous innovation such the one that "involve the dramatic leaps in terms of customers' familiarity in use" (p. 305). Scholars agree on the fact that the discontinuous innovation is displacing customers, generating "entirely new product categories" (Rice et al., 2002, p.330), and new behaviors, changing the customer habits (such as the microwave).

Scholars distinguished also between competence-enhancing or competence-destroying innovation. Freeman (1982) and later Abernathy and Clark (1985), gave the first definitions of 'revolutionary innovation', such as an 'innovation that disrupts and renders established technical and production competences obsolete'
(Freeman, p. 12). Also Tushman and Anderson (1987) observed that, under certain conditions, major technological shifts could be 'competence-destroying. At this point, new entrants would dominate the new industries that have been transformed by the introduction of new radical technologies. However, under other conditions, technologies were 'competence-enhancing', thereby strengthening the position of the existing incumbents. Importantly, this suggests that disruption is not always a 'changing of the guard' between existing incumbents and new entrants - as discussed by numerous studies (Bessant, 2008).

Many other leading scholars have considered the importance of business model innovation. Chesbrough (2007, 2010), Amit and Zott (2001, 2012), Teece (2010), Chesbrough and Rosenbloom (2002) and Gambardella and McGahan (2010), among others, considered the importance of innovation in a firm's strategy, organisation, and market orientation. Johnson et al. (2008) have identified when (at which stage of a sector's or firm's maturity) a new business model may emerge without disrupting incumbents.

They identified five 'strategic circumstances' (p. 64) when change could happen: (1) when there is the opportunity to create new markets (e.g., emerging markets) thanks to the introduction of new disruptive innovations, which could provide cheaper products for the customers; (2) when there is the opportunity to reshape a new business organisation; (3) when there is the possibility to finalise and improve products or services and, in doing so, changing the current business model, focusing increasingly on the 'job-must-be-done'; (4) when there is the opportunity of changing low-end markets; and (5) when firms can be able to be responsive to market competition introducing innovation. However, disruptive and breakthrough innovations are connected throughout the technology life cycle. In Figure 1 the Tushman and Rosenkopf (1992) model is presented, as adapted by Kaplan and Tripsas in 2008, which considers four 'standard stages' of the technology life cycle:

1. Technological discontinuity: The discovery of new technologies related to new scientific knowledge or a radical improvement in technological performance.

2. Variation - Era of ferment: This phase is characterised by technical uncertainty, high variation in customers' needs and preferences, and ambiguous user preferences.

3. Selection - Dominant design emergence: The preferences of the customers are established, and the common architecture of the new technology becomes a standard used by the majority of firms in the market.

4. Retention - Era of incremental change: The dominant design is still stable and difficult to displace; only marginal improvements are introduced. The focus of innovation activity is on incremental innovations. 
Figure 1: Technology life cycle

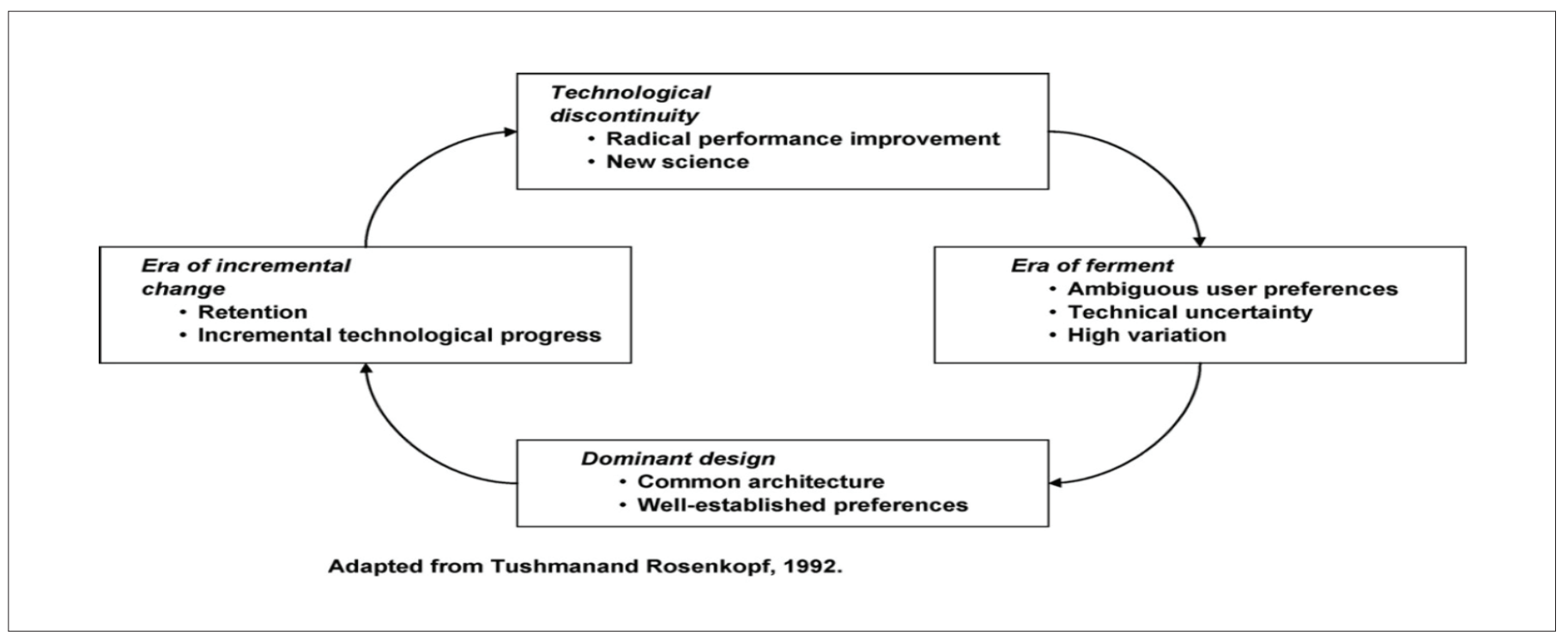

Source: Kaplan and Tripsas (2008).

Breakthrough innovation and disruptive innovations arise in the era of technological discontinuity, but, the breakthrough innovation is more specific on the technological trajectory of the product. Thus, the focus technological attributes of the product, and the firms' effort lies in finding of the new-to-the-world product. Instead, the disruptive innovation arises if markets are revolutionized. Therefore, when the new product arrives at the "era of ferment", the opportunity to generate a dominant design may be faster for the breakthrough innovation, rather than for disruptive. This is underlined in DIA (Discovery, Incubation, and Acceleration) system proposed by O'Connor (2009). In fact, the "acceleration" process refers to the opportunity to commercialize the new product, which can be considered the way to conduct the product from the era of ferment to the dominant design.

\section{Incremental versus radical innovation}

The OECD (Oslo Manual, 2018) defines innovation as 'a new or improved product or process (or combination thereof) that differs significantly from the unit's previous products or processes and that has been made available to potential users (product) or brought into use by the unit (process)' (p. 32). This type of innovation is often complex, and it is more likely to involve technological changes, and to mobilise different actors.

Incremental innovation is defined by the OECD as "small improvements on existing products and processes" (OECD, 2010; p. 35). In a working paper by Hamdan-Livramento, and Raffo (2016) incremental innovation is considered as the one that "usually involve a minor - but maybe significant - improvement on the existing technologies" (p. 4). Incremental innovation does not imply such large changes; instead, it represents only an improvement - in the technology, design, and use - of the product or process. Research and development (R\&D) investment in incremental innovation requires less effort. Scholars agree on the idea that incremental innovation is an update to, or an amelioration of something that already exists (Ettlie et al., 1984; Christensen, 1997; Lane, 2011, 2016; Utterbach and Acee, 2005; Hargadon, 2003; Ruttan, 1959; Benner and Tripsas, 2012; Tripsas, 1997a, 1997b, 2009).

The development of incremental innovation follows the path dependency highlighted by the emergence of a dominant design. Thus, scholars consider the incremental innovation more reliable by incumbents, because the lock-in process of path dependency occurs more frequently in big organizations.

Radical innovations, instead, according to Freeman (1992), represent a discontinuity in the industry; a change in the process, product or in the organisation. In fact, Freeman considered incremental innovation as a further development of an existing paradigm, in which firms reduce costs or prices, or they search for better product designs. In the literature, it is clear that radical innovation brings about a change in both firms and customers, and, consequently, in the market as well. This change derives from new investments (or search strategies) made by firms to discover new products or processes. Sometimes, radical innovations can emerge thanks to lead users (Von Hippel, 1986, 1988). The radical innovation changes the world, because it is something new to the firm, the customers, and the market. It is, in fact, new to the world. It happens when a technological discontinuity occurs and 'inaugurates an era of ferment' (p. 27) that promotes competition among the innovating firms to select the most appropriate form of innovation, which includes perfecting the design and improving the technical characteristics of the innovation itself (Tushman and Anderson, 1987).

The concept of radical innovation has always been contrasted with that of incremental innovation. According to many scholars, the difference between radical and incremental innovation can be easily identified. Radical innovations are those that change the world, 
something new for all firms and markets. The main difference that Chandy and Tellis (1998) proposed among radical and incremental innovation refers to the role of the technology and the market. The first dimension looks at which extent a technology adopted to obtain a new product is new; instead, the second dimension considers the opportunity to satisfy new customers' needs with respect to previous products. They looked at the radicalness of an innovation as the shock that affect the S-curve of the product diffusion, considering the changes needed to modify a product for the market. The more the core technology is modified to obtain a new product, the more the innovation is radical. On the contrary, if the shock comes from the market, it generates a market change. Substantially, the market demand shifts are less radical and involve small ameliorations and improvements of already existing products. Chandy and Tellis $(1998,2000)$ provide a good analysis of the capabilities and opportunity for firms to introduce an innovation. In their article of 2000 they focused on the dimension of the actors which introduce radical or incremental innovation in the market. They find out that it is likely that small or non-incumbent firms introduce radical innovations rather than big incumbents, because (as underlined by e.g. David, 1985; Liebowitz and Margolis, 1995; Tripsas 1998; Coombs and Hull 1998; Cavalcante et al., 2011) the path dependency process is strongly linked to the consolidated firms' internal routines, knowledge, capabilities, and resources. Those aspects are absent in small new entrant firms.

Menguc et al. (2014) have shown that the design of a product is relevant in numerous cases of product innovation. "Firms with incremental product innovation capability have the competency to deliver product innovations that depart minimally from existing routines, operations, and knowledge. Firms that possess such capabilities produce products that are seen by customers as ones that enhance the consumption experience without significantly disrupting or deviating from customers' prior knowledge or requiring new learning" (p. 316). In contrast, the radical innovation process in products lies in the idea that there is a need of "unlearning and more cognitive effort" (p. 316) for customers in the use of the new product.

Scholars agree on the fact that a radical innovation occurs less frequently than an incremental one. Radical innovations are a supplydriven, not a demand-driven, phenomenon. Tripsas (2008) considered the fact that technological change is often driven by customer preferences along four dimensions:

1. Relevant attributes: customers' preferences about different given sets of attributes of the product;

2. Minimum performance requirement: a product must meet the minimum performance threshold level before the customer will include it in the set of possible purchases;

3. Maximum value performance: in many cases, customers may be attracted to high performance, and they may be willing to spend more if the new product exhibits these characteristics;
4. Relative preference for specific attributes: all customers have different personal opinions about the value of a product, according to their particular tastes.

Thus, even though Tripsas used the word 'radical' to define the technological discontinuities occurring in an industry, she considered the changing of the customer preferences as the most important factor. She did not reflect on the radical changes that may occur in the structure of the market because of the introduction of a radical innovation. This approach is quite different from that one adopted by Christensen with his idea of market subversion due to the entry of a disruptive technology.

According to David (2001), path dependency concept "refers to a property of contingent, non-reversible dynamical processes, including a wide array of biological and social processes that can properly be described as 'evolutionary"' (p.1). Considering the lock-in process, he looks at big firms that are unable to create radical innovations. They follow only the path of incremental innovation. Path dependency exists when big firms have an intrinsic inability to operate a different set of choices in resources allocation. A large body of the literature has examined the path dependency theory together with the resource based view theory, including the dynamic capabilities approach (Coombs and Hull, 1998; Danneels, 2002; Broring, 2010; DaSilva and Trkman, 2014). Also Tripsas (2009) examined the lock-in process in firms. The scholar was interested in analysing firms' identities. Thus, she assessed the emergence of a disruptive innovation that forces firms to change their foci and, in doing so, their identity. She considered two types of identities: (1) internal, linked to the shared understanding of the employees regarding the firm core business; and (2) external, related to the outside audience (firm stakholders). In this contribution, she also argued that incumbent firms are less likely to change their core business because of their internal identity, which consequently leads to some missed opportunities in introducing new technologies in their markets (or, in an extreme case, even to the failure of the firm).

\section{Breakthrough innovation}

As presented in the introduction, in order to distinguish the difference between breakthrough innovation and disruptive innovation we search in Google Scholar the more cited articles.

'Breakthrough' innovation is a term used in the literature in the 2000s, in the era of emerging ICT technologies, to define radical innovation; this term is used as a synonym of radical or discontinuous innovation. The term "breakthrough innovation" has been used frequently in a large body of literature (Rice et al., 1998; McDermott and O'Connor, 2002; O'Connor et al., 2002; O'Connor and Rice, 2013). The concept of breakthrough innovations rises strongly among scholars after 2002, with an acceleration after 2012. Figure $2^{1}$ shows the evolution of the number of papers written in breakthrough innovation field.

A snowball process has been adopted (Wholin, 2014); Lecy and Beatty, 2012). We will start to comment the first search referred to the

'The search was run in Scopus Database looking at all documents referring to "breakthrough innovation*”, written in English between 1957 and 2019. 
term "breakthrough innovation". Paper n. 1 was From experience: harnessing tacit knowledge to achieve breakthrough innovation (Mascitelli, 2000; cited 525 times), n. 2. Opportunity recognition and breakthrough innovation in large established firms (O'Connor and Rice, 2001; cited 384 times), and n. 3 . The double-edged sword of recombination in breakthrough innovation (Kaplan and Vakili, 2015; cited 246 time).

Figure 2. Number of documents referring to breakthrough innovation from 1957 to 2019

\section{Documents by year}

\section{Scopus}

25

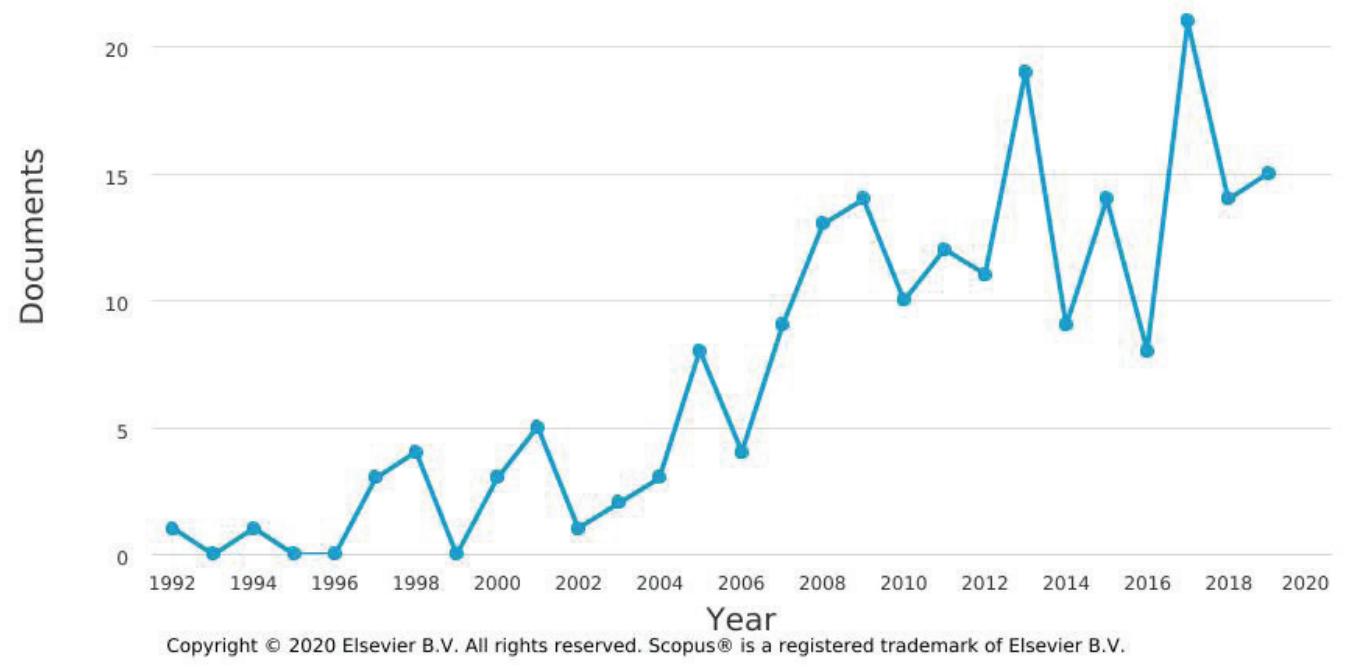

Source: Author's search in Scopus Database.

O'Connor's contributions, for instance, explore the management of innovation projects in firms. She proposes a useful guideline for entrepreneurs and managers to successfully (and quickly) develop or absorb novel and radical innovations.

Barnholt (1997) and Mascitelli (2000) used this terminology to classify revolutionary technological changes. In their vision, a breakthrough is an innovation that often occurs unexpectedly, due to a creative process emerging in an organisation. This innovation breaks the previous technological paradigm and creates a new trajectory. This conceptualisation is synonymous with that of revolutionary technical change, as discussed in the 1980s by the Sussex school and, particularly, by Freeman (1982). In particular, Mascitelli (2000) defines breakthrough innovations as the processes which "represent any creative and original action by individuals or project teams that enables firms to capture at least temporary monopoly profits or that results in a significant increase in market share" (p. 181).

In contrast, in the O'Connor's contribution (O'Connor and Rice, 2013; Roberson and O'Connor, 2013), the focus is placed on how to manage the development of new radical innovations. Hence, in her definition of breakthrough innovation, we can assume that a breakthrough innovation is an activity that is planned, and well defined by the firm. In particular, in O'Connor and Rice (2001) it is clarified what is a breakthrough innovation: a "radical or breakthrough innovation as the creation of a new line of business - new for both the firm and the market place. By new we mean a product or process either with unprecedented performance features" (p. 99). This contribution examines twelve case studies. O'Connor shares a similar view with Mascitelli (2000) and Barnholt (1997). In fact, for them "as breakthrough innovation project proceeds, there is an increased commitment of financial and human capital" (p. 104), and "the capacity of the firm for opportunity recognition is related to the continuity of the informal networks of individuals engaged in the conversion of breakthrough innovations into new ventures" (p. 107). Thus, on the one hand, the "informal networks", represented by the individuals involved in the innovation projects is relevant. On the other hand, in all those contributions emerge that the breakthrough innovation is a planned activity, which need the creativity of the individuals. The innovation output and the commercialization is of course the last step of the process, but, interesting to observe, these authors are not studying the effects of the innovation on the market dynamics. Moreover, in O'Connor and Rice (2001), Rice et al. (2002), and O'Connor et al., (2008) the examples used are constructed on large incumbents rather than on small new entrants. In any case, this literature is centred on incumbents which have the attitude, competence, and capability to manage a radical innovation process without being displaced by innovative entrants. 
In fact, firms rely on projects where the innovation process is driven by already existing competences, and for this reason breakthrough innovation is specular to their dynamic capabilities. As it is known, dynamic capabilities (Teece, 1994, and 2014; Teece and Pisano, 1994; Teece et al. 1997; Eisenhardt and Martin, 2000, Winter, 2003; Drnevich and Kriauciunas; 2011; Wilden and Gudergan, 2015) are processes and routine practices, which are aimed to support the firms' organization in order to generate competitive advantage. Hence, dynamic capabilities and routines seem to support breakthrough innovation. Therefore, we can consider the breakthrough innovation process as an activity that needs dynamic capabilities, but which may also be a competence enhancing process (Kelley et al., 2009; O'Connor, 2009; Kelley et al., 2011).

Other authors share this view, such as McDermott and Handfield (2000) and Dunlap-Hinkler et al. (2010): a breakthrough innovation happens a priori in the enterprise through well-planned projects and a result of technological exploration (March, 1991; O’Reilly and Tushman, 2004).

They focused exclusively on large companies that had established processes in place, and that had a "critical mass" of resources available to dedicate to their new product development efforts.

However, a significant number of innovations that transform an industry do not originate from the industry's leaders (Henderson and Clark, 1990; Utterback, 1994). Often incumbents may prefer to follow an established trajectory, instead of pursuing a new direction that is more radical. Henderson (1993) suggested that, in some circumstances, extensive experience with a technology might have a substantial disadvantage, creating a resistance to change. Technological shifts open up a new fluid phase that may evolve into multiple directions. Incumbent firms may find difficult to rely on new, radical and breakthrough technologies (Phillips et al., 2006).

\section{Disruptive innovation}

Because disruptive innovation, generates new markets, displacing the incumbents, as pointed by Christenseen (1997), it is often developed by new firms. This approach will be discussed in this section.

Adopting the same methodology of the previous section, the search in Google scholar has found three important papers. The first is 1. What is disruptive innovation (Christensen at al., 2015; cited 1430 times); 2. Disruptive innovation for social change (Christensen et al., 2006; cited 762 times), and 3. Disruptive innovation: in need of better theory (Markides, 2006; cited 1313 times).

Schumpeter (1942) proposed in origin the first interpretation of 'creative destruction' in his theory of economic change. He considered the innovation process from an economic viewpoint, as a 'process of industrial mutation [...] that incessantly revolutionises the economic structure from within, incessantly destroying the old one, incessantly creating a new one' (p. 83). His idea has been re-proposed by Christensen (1997), under the new terminology of 'disruptive innovation', as an innovation that displaces firms from the market.
Specifically, Christensen (1997) stresses that a disruptive technology has five important characteristics. First, new disruptive products are usually 'simpler, cheaper, more reliable and convenient than established products'. Second, leading customers usually cannot shift to the new disruptive technology because of the existence of an older dominant design. Third, the new technology underperforms when compared with the older technology. Fourth, disruptive technologies improve performance after market entry because producers can benefit from learning by doing, and learning by experimenting. Fifth, at a certain point, the disruptive innovation displaces the old technology and, therefore, new entrants displace the incumbent firms.

Moreover, in The Innovator's Dilemma, Christensen explains the weakness of incumbent firms: "1. Resource dependence: Customers effectively control the patterns of resource allocation in well-run companies. 2. Small markets don't solve the growth needs of sales of large companies. 3. The ultimate uses or applications for disruptive technologies are unknowable in advance. Failure is an intrinsic possibility, and success can come only after several attempts. 4. The attributes that make disruptive technologies unattractive in established markets often are the very important in emerging markets" (p. 57).

It can be noted that disruptive technology is not necessarily a new product (or a new process) that performs better than the previous one, but rather a product that creates new markets and new opportunities and, as such, can destabilise the incumbents. An empirical example can be the e-commerce. It is a branch of the Internet, so it is an extension of a previously existing technology, and it is fulfilling the need of customers to buy goods online. When the e-commerce has begun to be adopted, mainly with amazon.com, and also with other different platforms, it has widely changed the market structure, generating new opportunities and threats, and the entry of new firms.

Whereas in his early model Christensen stressed disruption from below (in which a simpler and cheaper technology displaces an established but over-sophisticated one), in his later model he also included the case of 'new market' disruption, where the focus is on unmet or unimagined needs that creates new market segments (Christensen and Raynor, 2003). Moreover, Christensen and Reynor (2003) argued that 'disruption is a process' (p. 69), which implies that disruption does not occur only in just one given moment. It is a process that continues over time. Danneels (2004) agreed on this point, considering new innovative entrants into an industry as the possible cause of incumbents' displacement in their market. As discussed by Christensen, incumbents are often lazy: They do not want to invest in new market niches that do not have a significant size.

The replacement of incumbents by new entrants in the market happens because (some) existing firms fail. According to Tellis (2006), Benner and Tripsas (2012), Tripsas (1997a, 1997b), Bower and Christensen (1995) and Adner and Zemsky (2003), incumbents fail due to the absence of investments in the new technology, or in the presence of weak capabilities in new technology absorption. This illustrates the case in which firms make the wrong set of choices to manage the 
discontinuous technology. Markides (2006) was clear in maintaining that business model innovation usually creates a new market niche without completely overtaking the traditional way of competing. In fact, the e-commerce generated new threats but also new opportunities, not just for new entrants (such as in 1990s were amazon.com, e-bay, or yoox.com), but also for incumbents, which were operating in the old model of selling through physical stores (e.g. Inditex Group, Benetton, or H\&M). Several incumbents were able to absorb the innovation, and to foster the changes occurring in the market, which have affected their business model, as well. In doing so, the incumbents have demonstrated that they were able to develop a new business model, adopting the new technology.

The important thing to stress is that certainly, as argued also by Utterback and Acee (2005) disruptive technologies create new market niches. Niches are typically small portions of the main market. They cannot guarantee good profitability or even the survival of the incumbents (assumed to be large organisations).

Tellis (2006) has argued that the lack of investment in the new disruptive technology (or in a related $R \& D$ activity) is motivated by the absence of leadership. The firms often lack of 'visionary leadership'. But the Christensen's definition of disruptive innovation suffers from a problem of identification (Danneels $(2002,2004)$. How can we define a disruptive technology a priori, before it has shown its potential? Tripsas' contribution to the innovation literature appears, in this theoretical context, to be very interesting. Tripsas (1997a, 1997b) analysed the history of the typesetting industry to show that there is no deterministic outcome deriving from the market entry of disruptive technologies. Her argument can somewhat be related to Tellis' idea of visionary leadership. Her reasoning was further developed in Benner and Tripsas (2012) and Tripsas (2009), in relation to the history of the digital camera industry, considering the capability of firms to manage the introduction of digital technologies. The entry of disruptive innovations opens opportunities to develop new markets and new products, but these opportunities are also open to new firms and incumbents. Firms may miss these opportunities because they are incapable of changing their identity ('prior industry affiliation', p. 279).

An interesting contribution was presented by Markides (2006), who has distinguished between disruptive technologies (causing a potentially high impact on the industry) and disruptive innovations, which not only affect a specific technology applied to a novel product, but also the evolution of the market structure, or the introduction of a new business model.

Markides (2010, 2012) and Markides and Oyon (2010) have defined the characteristic of new business models deriving from the introduction of radical changes and disruptive innovations. Disruptive innovations generate new markets and provide a better balance between costs and performances. Disruptive innovations can create important new market niches, as, for instance, this has occurred in the case of low-cost airlines. Also in the case of the retail industry, after the entrance of new e-commerce modalities, that pushed incumbents to re-design their old business model. The omnichannel strategy is nowadays dominant. The click-and-collect modality is widely spread in the retail industry and this approach is combining the in-store and online customer experience. Moreover, also the mobile-phone applications represent a new opportunity to communicate with customers.

\section{Discussion. Breakthrough and disruptive innovation}

Considering the existence of different types of radical innovations that have been analysed in detail, in the previous paragraphs, here are reported some main lines of reflection regarding the issue of breakthrough innovation and disruptive innovation. On the one hand, these two types of radical innovations are similar, and both regard revolutionary changes. We can assume that both innovations lead to some big changes occurring in the market (disruptive) or in the technology related to a product (breakthrough).

According to Christensen (1997), disruptive innovations are not 'sustaining' innovations, they are mainly competence-destroying because market niches are not sufficiently large for the growth of the incumbent firms. In contrast, these niches are a good starting point for small firms that want to develop disruptive innovations, creating new needs for novel customers. Disruptive innovation and is associated with a displacement of incumbents. In Markides interpretation, disruptive innovations generate disruptive new business models, but their power of disruption is limited to a minor, but significant, share of the market. Thus, old and disruptive technology tend to survive together in the medium- or long-term.

Moreover, because of the small size of these firms (which can also be a spin-off of incumbent firms), the turnover coming from the niches is enough to guarantee their survival. Markides and Geroski (2005) also advocated this approach. Established companies should not even attempt to create disruptive innovations but should instead leave this task to small start-up firms, which have the requisite to succeed in this game. Established firms should concentrate on what they are good at - that is, consolidating young markets into the big mass market. It means that the small businesses are able to create disruptive innovations, which are cheaper to be produced (because generally they require more creativity than strong efforts in $\mathrm{R} \& \mathrm{D}$ activity).

Another line of reflection has been proposed by Tripsas (1997a; 1997b, 2009, 2012). The incumbents are able to change their approach in order to manage and absorb the new innovation which, in the case of business model innovation, refers more to a process and a strategy then to a physical attribute of a product. We can easily assume that several large players are able to manage the disruptive innovation, rather than small incumbents, which may suffer more. But in other cases, incumbents are not able to shift to new technology and they exit the market.

Finally, we can resume arguing that breakthrough innovations refer more to the product innovation, and they are done both by large firms (incumbents on the market) and by small innovators. The term the disruptive innovation looks at a different phenomenon, when an innovation displaces the incumbents, shifting not just the technology 
but the industry structure, suggesting that the disruption is more related to the market structure rather than to the technological advancement of the product per se.

An example is provided by the retail industry, with the spread of ecommerce. As discussed before, e-commerce represents a potentially disruptive innovation. Actually only large retail chains have been adopted it. In contrast, traditional small shops may be incapable to use this new technology. However, several small new start-ups were created in the last decade that only sell-online.

\section{Conclusions}

The main idea of this work was to contribute to the development of a unique distinction among the definitions of breakthrough and disruptive innovation. Scholars have developed different definitions, such as disruptive and breakthrough innovations. The main differences between disruptive and breakthrough innovation are due to a few key points. A disruptive innovation disrupts the market and creates new market niches. It is an innovation that not only involves the product or the process but it can also affect the firm's business model and the processes of entry and firms' shakeout. Considering its characteristics, it is a competence destroying innovation. Disruptive innovations in product life cycles reflect the poorer product performance (or the excessive price of the previous used technology). Existing customers do not yet consider the new product, but novel customers are attracted. This radical innovation affects competition in the market, creating new products that satisfy new needs. In new market niches, innovative firms can grow and, and at the end of the market evolution, they can displace the incumbents. When new technologies are introduced without changing the firms' rankings in the market, then these innovations might just be considered technological breakthroughs.

A breakthrough innovation is a radical innovation that does not dramatically provoke the displacement of old firms from the market (and it originates in large firms as well or in new small firms entering the market without the power of becoming dominant), allowing new actors to conquering only a small percentage of total industry sales. Breakthrough innovations refer only to new technologies, and to the invention of new products, and they do not pertain to new business models. Referring to the competencies necessarily to create a breakthrough innovation, if this process is originated in a large firm, it is a more competence enhancing process, because it relies to the development of new projects and well planned activities, internal to the existing know-how of the firm. Nevertheless, clearly, new inventors or, more infrequently innovative start-ups, can create breakthrough innovations (Hervas-Oliver. \& Boix-Domenech, 2013). New business models can be disruptive or non-disruptive. They can create new niches in old markets or new markets, increasing competition for both new and incumbent firms.

The entire displacement of incumbents in an industry is a rare phenomenon. Thus, Christensen's theory has not found much empirical verification, despite its popularity. Moreover, it is interesting to observe the capacity of the incumbent to absorb potentially 'disruptive' innovations.
Possessing the dynamic capabilities to fast react and recognising a disruptive innovation, in order to be able to absorb it, appears to be important in helping firms to define the best way to compete. This can spur incumbents to unfold the lock-in process, related to the existence of a strong internal identity. If an innovation has the nature of being disruptive, then firms must focus on it, finding the right managers capable of absorbing, or at least to react quickly. The possession of dynamic capabilities, or in general the ability to size an opportunity, and the courage to strengthen firms R\&D activity, can help incumbents to survive in the market.

\section{References}

Abernathy, W. J., \& Clark, K. B. (1985). Innovation: Mapping the winds of creative destruction. Research policy, 14(1), 3-22.

Adner, R., \& Levinthal, D. (2001). Demand heterogeneity and technology evolution: implications for product and process innovation. Management science, 47(5), 611-628.

Adner, R., \& Zemsky, P. B. (2003). Disruptive technologies and the emergence of competition.

Ali, A., Krapfel Jr, R., \& LaBahn, D. (1995). Product innovativeness and entry strategy: Impact on cycle time and break-even time. Journal of Product Innovation Management, 12(1), 54-69.

Amit, R., \& Zott, C. (2001). Value creation in e-business. Strategic management journal, 22(6-7), 493-520.Amit, R., \& Zott, C. (2012). Creating value through business model innovation. MIT Sloan Management Review, 53(3), 41.

Amit, R., \& Zott, C. (2012). Creating value through business model innovation. MIT Sloan Management Review, 53(3), 41-49.

Atuahene-Gima, K. (1995). An exploratory analysis of the impact of market orientation on new product performance: a contingency approach. Journal of Product Innovation Management, 12(4), 275-293.

Barnholt, E.W., 1997. Fostering business growth with breakthrough innovation. Research-Technology Management, 40, 12-16.

Benner, M. J., \& Tripsas, M. (2012). The influence of prior industry affiliation on framing in nascent industries: the evolution of digital cameras. Strategic Management Journal, 33(3), 277-302.

Bessant, J. (2008). Dealing with discontinuous innovation: The European experience, International Journal of Technology Management, $42(1 / 2), 36-50$

Bower, J. L., \& Christensen, C. M. (1995). Disruptive technologies: catching the wave.

Broring, S. (2010). Developing innovation strategies for convergence. Is 'open innovation' imperative? International Journal of Technology Management, 49(1), 272. 
Cavalcante, S., Kesting, P., \& Ulhøi, J. (2011). Business model dynamics and innovation:(re) establishing the missing linkages. Management decision, 49(8), 1327-1342.

Chandy, R. K., \& Tellis, G. J. (1998). Organizing for radical product innovation: The overlooked role of willingness to cannibalize. Journal of marketing research, 35(4), 474-487.

Chandy, R. K., \& Tellis, G. J. (2000). The incumbent's curse? Incumbency, size, and radical product innovation. Journal of marketing, 64(3), 1-17.

Chesbrough, H. (2007). Business model innovation: it's not just about technology anymore. Strategy \& Leadership, 35(6), 12-17.

Chesbrough, H. (2010). Business model innovation: opportunities and barriers. Long Range Planning, 43(2), 354-363.

Chesbrough, H., \& Rosenbloom, R. S. (2002). The role of the business model in capturing value from innovation: evidence from Xerox Corporation's technology spin-off companies. Industrial and corporate change, 11(3), 529-555.

Christensen, C. (1997). The innovator's dilemma. Harvard Business School Press, Cambridge, Mass.

Christensen, C. M., Baumann, H., Ruggles, R., \& Sadtler, T. M. (2006). Disruptive innovation for social change. Harvard business review, 84(12), 94.

Christensen, C. M., Raynor, M. E., \& McDonald, R. (2015). What is disruptive innovation. Harvard business review, 93(12), 44-53.

Christensen, C., \& Raynor, M. (2003). The innovator's solution: Creating and sustaining successful growth. Harvard Business Review Press.

Coombs, R., \& Hull, R. (1998). 'Knowledge management practices' and path-dependency in innovation. Research policy, 27(3), 239-256.

Danneels, E. (2002). The dynamics of product innovation and firm competences. Strategic management journal, 23(12), 1095-1121.

Danneels, E. (2004). Disruptive technology reconsidered: A critique and research agenda. Journal of product innovation management, 21(4), 246-258.

DaSilva, C. M., \& Trkman, P. (2014). Business model: What it is and what it is not. Long range planning, 47(6), 379-389.

David, P. A. (1985). Clio and the Economics of QWERTY. The American economic review, 75(2), 332-337.

David, P. A. (2001). Path dependence, its critics and the quest for 'historical economics'. Evolution and path dependence in economic ideas: Past and present, 15, 40.

Drnevich, P. L., \& Kriauciunas, A. P. (2011). Clarifying the conditions and limits of the contributions of ordinary and dynamic capabilities to relative firm performance. Strategic management journal, 32(3), 254-279.
Dunlap-Hinkler, D., Kotabe, M., \& Mudambi, R. (2010). A story of breakthrough versus incremental innovation: Corporate entrepreneurship in the global pharmaceutical industry. Strategic Entrepreneurship Journal, 4(2), 106-127.

Eisenhardt, K. M., \& Martin, J. A. (2000). Dynamic capabilities: what are they?. Strategic management journal, 21(10-11), 1105-1121.

Ettlie, J., W. Bridges and R. O'Keefe (1984). Organization strategy and structural differences for radical versus incremental innovation. $\mathrm{Ma}$ nagement Science, 30: 682-695

Freeman, C. (1982). The Economics of Industrial Innovation, Pinter, London (second edition).

Freeman, C. (1992). The Economics of Hope. New York, New York, Pinter Publishers

Galunic, D. C., \& Eisenhardt, K. M. (2001). Architectural innovation and modular corporate forms. Academy of Management journal, 44(6), 1229-1249.

Galunic, D. C., \& Rodan, S. (1998). Resource recombinations in the firm: Knowledge structures and the potential for Schumpeterian innovation. Strategic management journal, 19(12), 1193-1201.

Gambardella, A., \& McGahan, A. M. (2010). Business-model innovation: General purpose technologies and their implications for industry structure. Long Range Planning, 43(2), 262-271.

Garcia, R., \& Calantone, R. (2002). A critical look at technological innovation typology and innovativeness terminology: a literature review. Journal of Product Innovation Management, 19(2), 110-132.

Green, S. G., Gavin, M. B., \& Aiman-Smith, L. (1995). Assessing a multidimensional measure of radical technological innovation. IEEE transactions on engineering management, 42(3), 203-214.

Hamdan-Livramento, I., \& Raffo, J. (2016). What is an incremental but non-patentable invention. WIPO, Economics and Statistics Division working paper.

Hargadon, A. (2003). How breakthroughs happen: The surprising truth about how companies innovate. Harvard Business Press.

Henderson, R. M. (1993). Underinvestment and incompetence as responses to radical innovation: Evidence from the photolithographic alignment equipment industry. The RAND Journal of Economics, 248-270.

Henderson, R. M., \& Clark, K. B. (1990). Architectural innovation: The reconfiguration of existing product technologies and the failure of established firms. Administrative science quarterly, 9-30.

Hervas-Oliver, J. L., \& Boix-Domenech, R. (2013). The economic geography of the meso-global spaces: Integrating multinationals and clusters at the local-global level. European Planning Studies, 21(7), $1064-1080$ 
Johnson, M.W., Christensen, C.M., Kagermann, H. (2008). Reinventing Your Business Model. Harvard Business Review, 86, 50.

Kaplan, S., \& Tripsas, M. (2008). Thinking about technology: Applying a cognitive lens to technical change. Research Policy, 37(5), 790-805.

Kaplan, S., \& Vakili, K. (2015). The double-edged sword of recombination in breakthrough innovation. Strategic Management Journal, 36(10), 1435-1457.

Kelley, D. J., O’Connor, G. C., Neck, H., \& Peters, L. (2011). Building an organizational capability for radical innovation: The direct managerial role. Journal of Engineering and Technology Management, 28(4), 249-267.

Kelley, D. J., Peters, L., \& O'Connor, G. C. (2009). Intra-organizational networking for innovation-based corporate entrepreneurship. Journal of Business Venturing, 24(3), 221-235.

Kleinschmidt, E. J., \& Cooper, R. G. (1991). The impact of product innovativeness on performance. Journal of Product Innovation Management, 8(4), 240-251.

Kline, S. J., \& Rosenberg, N. (1986). An overview of innovation. The positive sum strategy: Harnessing technology for economic growth, 14, 640.

Lane, D. A. (2011). Complexity and innovation dynamics. Handbook on the economic complexity of technological change, 63-80.

Lane, D. A. (2016). Innovation cascades: artefacts, organization and attributions. Phil. Trans. R. Soc. B, 371(1690), 20150194.

Lecy, J. D., \& Beatty, K. E. (2012). Representative literature reviews using constrained snowball sampling and citation network analysis. Available at SSRN 1992601.

Lee, M., \& Na, D. (1994). Determinants of technical success in product development when innovative radicalness is considered. Journal of Product Innovation Management, 11(1), 62-68.

Liebowitz, S. J., \& Margolis, S. E. (1995). Path dependence, lock-in, and history. Journal of Law, Economics, \& Organization, 205-226.

Magnusson, T., Lindström, G., \& Berggren, C. (2003). Architectural or modular innovation? Managing discontinuous product development in response to challenging environmental performance targets. International Journal of Innovation Management, 7(01), 1-26.

March, J. G. (1991). Exploration and exploitation in organizational learning. Organization science, 2(1), 71-87.

Markides, C.C. (2006). Disruptive innovation: In need of better theory. Journal of product innovation management, 23(1), 19-25.
Markides, C. C. (2012). How disruptive will innovations from emerging markets be?. MIT Sloan Management Review, 54(1), 23.

Markides, C. C. and Geroski P. (2005) Fast second: how smart companies bypass radical innovation to enter and dominate new markets. San Francisco, Jossey-Bass Pub.

Markides, C., \& Oyon, D. (2010). What to do against disruptive business models (when and how to play two games at once). MIT Sloan Management Review, 51(4), 25.

Mascitelli, R., 2000. From experience: Harnessing tacit knowledge to achieve breakthrough innovation. Journal of Product Innovation Management, 17, 179-193.

McDermott, C., \& Handfield, R. (2000). Concurrent development and strategic outsourcing: do the rules change in breakthrough innovation? The Journal of High Technology Management Research, 11(1), 35-57.

Menguc, B., Auh, S., \& Yannopoulos, P. (2014). Customer and supplier involvement in design: The moderating role of incremental and radical innovation capability. Journal of Product Innovation Management, 31(2), 313-328.

O'Connor, G. C. (1998). Market learning and radical innovation: A cross case comparison of eight radical innovation projects. Journal of Product Innovation Management, 15(2), 151-166.

O'Connor, G. C. (2009). Sustaining breakthrough innovation. Research-Technology Management, 52(3), 12-14.

O'Connor, G. C., \& Rice, M. P. (2001). Opportunity recognition and breakthrough innovation in large established firms. California Management Review, 43(2), 95-116.

O'Connor, G. C., \& Rice, M. P. (2013). New market creation for breakthrough innovations: Enabling and constraining mechanisms. Journal of Product Innovation Management, 30(2), 209-227.

O’Connor, G. C., Hendricks, R., \& Rice, M. P. (2002). Assessing transition readiness for radical innovation. Research-Technology Management, 45(6), 50-56.

O’Connor, G. C., Ravichandran, T., \& Robeson, D. (2008). Risk management through learning: Management practices for radical innovation success. The Journal of High Technology Management Research, 19(1), 70-82.

OECD (2012) Background paper, in Proceedings of the OECD/European Commission/Nordic Innovation Joint Workshop $19^{\text {th }}-20^{\text {th }}$ January 2012. Denmark: Copenhagen.

OECD Publishing. (2010). Oecd Studies On Smes And Entrepreneurship Smes, Entrepreneurship And Innovation. OECD Publishing. 
OECD/Eurostat (2018), Oslo Manual 2018: Guidelines for Collecting, Reporting and Using Data on Innovation, 4th Edition, The Measurement of Scientific, Technological and Innovation Activities, OECD Publishing, Paris/Eurostat, Luxembourg.

Olson, E. M., Walker Jr, O. C., \& Ruekert, R. W. (1995). Organizing for effective new product development: The moderating role of product innovativeness. The Journal of Marketing, 48-62.

O’Reilly, C. A., \& Tushman, M. L. (2004). The ambidextrous organization. Harvard business review, 82(4), 74-81.

Pavitt, K. (2005). Innovation processes. The Oxford handbook of innovation, 86-114.

Phillips, W., Noke, H., Bessant, J. and Lamming, R. (2006) 'Beyond the steady state: managing discontinuous product and process innovation', International Journal of Innovation Management, Vol. 10, No. 2.

Rice, M. P., Leifer, R., \& O'Connor, G. C. (2002). Commercializing discontinuous innovations: bridging the gap from discontinuous innovation project to operations. IEEE Transactions on Engineering $\mathrm{Ma}$ nagement, 49(4), 330-340.

Rice, M. P., O’Connor, G. C., Peters, L. S., \& Morone, J. G. (1998). Managing discontinuous innovation. Research-Technology Management, $41(3), 52-58$.

Robertson, T. S. (1967). The process of innovation and the diffusion of innovation. Journal of marketing, 31(1), 14-19.

Ruttan, V. W. (1959). Usher and Schumpeter on invention, innovation, and technological change. The quarterly journal of economics, 596-606.

Sanchez, R., \& Mahoney, J. T. (1996). Modularity, flexibility, and knowledge management in product and organization design. Strategic management journal, 17(S2), 63-76.

Schumpeter, J. (1942). Capitalism, Socialism and Democracy. New York: Harper Brothers

Small, H. (1973). Co-citation in the scientific literature: A new measure of the relationship between two documents. Journal of the American Society for information Science, 24(4), 265-269.

Sood, A., \& Tellis, G. J. (2005). Technological evolution and radical innovation. Journal of Marketing, 69(3), 152-168.

Teece, D. J. (2010). Business models, business strategy and innovation. Long range planning, 43(2-3), 172-194.

Teece, D. J., Pisano, G., \& Shuen, A. (1997). Dynamic capabilities and strategic management. Strategic management journal, 18(7), 509-533.
Teece, D., \& Pisano, G. (1994). The dynamic capabilities of firms: an introduction. Industrial and corporate change, 3(3), 537-556.

Tripsas, M. (1997a). Unraveling the process of creative destruction: Complementary assets and incumbent survival in the typesetter industry. Strategic Management Journal, 119-142.

Tripsas, M. (1997b). Surviving radical technological change through dynamic capability: Evidence from the typesetter industry. Industrial and corporate Change, 6(2), 341-377.

Tripsas, M. (2008). Customer preference discontinuities: A trigger for radical technological change. Managerial and decision economics, 29(2-3), 79-97.

Tripsas, M. (2009). Technology, identity, and inertia through the lens of “The Digital Photography Company”. Organization Science, 20(2), 441-460.

Tushman, M. L., \& Anderson, P. (1987). Technological discontinuities and organizational environments. Administrative science quarterly, 439-465.

Tushman, M. L., \& Rosenkopf, L. (1992). Organizational determinants of technological-change-toward a sociology of technological evolution. Research in organizational behavior, 14, 311-347.

Utterback, J. M., \& Acee, H. J. (2005). Disruptive technologies: An expanded view. International Journal of Innovation Management, 9(01), 1-17.

Utterback, J. M. (1994). Mastering the Dynamics of Innovation: How Companies Can Seize Opportunities in the Face of Technological Change. University of Illinois at Urbana-Champaign's Academy for Entrepreneurial Leadership Historical Research.

Von Hippel, E. (1986). Lead users: a source of novel product concepts. Management science, 32(7), 791-805.

Von Hippel, E. (1988). The Sources of Innovation, Nueva York: Oxford University Press.

Wilden, R., \& Gudergan, S. P. (2015). The impact of dynamic capabilities on operational marketing and technological capabilities: investigating the role of environmental turbulence. Journal of the Academy of Marketing Science, 43(2), 181-199.

Winter, S. G. (2003). Understanding dynamic capabilities. Strategic management journal, 24(10), 991-995.

Wohlin, C. (2014, May). Guidelines for snowballing in systematic literature studies and a replication in software engineering. In Proceedings of the 18th international conference on evaluation and assessment in software engineering (pp. 1-10). 
